\title{
Artelogie
}

Recherche sur les arts, le patrimoine et la littérature de l'Amérique latine

17| 2021

Transformaciones en Cuba contemporánea: cultura y sociedad

Hombres negros que en silencio miran a cámara: Agencia afrodescendiente, descolonización y representación de masculinidades en pugna en el vídeo cubano (1997-2014)

\section{Suset Sánchez Sánchez}

\section{OpenEdition}

\section{Journals}

Edición electrónica

URL: https://journals.openedition.org/artelogie/10124

DOI: 10.4000/artelogie.10124

ISSN: 2115-6395

Editor

Association ESCAL

Referencia electrónica

Suset Sánchez Sánchez, «Hombres negros que en silencio miran a cámara: Agencia

afrodescendiente, descolonización y representación de masculinidades en pugna en el vídeo cubano (1997-2014)», Artelogie [En línea], 17 | 2021, Publicado el 27 septiembre 2021, consultado el 14 septiembre 2022. URL: http://journals.openedition.org/artelogie/10124; DOI: https://doi.org/10.4000/ artelogie. 10124

Este documento fue generado automáticamente el 14 septiembre 2022.

All rights reserved 


\section{Hombres negros que en silencio} miran a cámara: Agencia afrodescendiente, descolonización y representación de masculinidades en pugna en el vídeo cubano (1997-2014)

\section{Suset Sánchez Sánchez}

Introducción.

El silencio forma un nudo formado entre algo que es un instante y algo que es hablante o no: el otro. Es ese nudo cerrado que puede resonar cuando lo atraviesa y hasta que lo agujerea el grito.

(LACAN, 1964-1965: s.p.)

¡Oh, cuerpo mío, haz siempre de mí un hombre que interroga!

(FANON, 2009: p.190)

1 El primer caso de censura cultural que acontece en Cuba tras el triunfo revolucionario de 1959 fue el veto a la exhibición en los cines nacionales del corto documental PM, realizado por Sabá Cabrera Infante (Gibara, 1933 - Miami, 2002) y Orlando Jiménez Leal (La Habana, 1941) en 1961ํ․ El Instituto Cubano de Cine e Industria Cinematográficos (ICAIC) fue fundado en el mismo año 1959 por decreto de una Ley ministerial para 
sustentar uno de los pilares fundamentales de la política revolucionaria en materia cultural y desempeñar la función de propaganda y educación que demandaba el cine al servicio de la revolución y la construcción de la nueva sociedad. Fue dicha prohibición y la polémica que despertó en diferentes círculos intelectuales del país lo que dio paso al célebre discurso de Fidel Castro conocido como Palabras a los intelectuales y a la archiconocida frase: "Dentro de la Revolución, todo; contra la Revolución, nada". Con esa lapidaria sentencia quedaba clausurada la confrontación entre el poder político y los agentes del campo de la cultura sobre las condiciones de la creación y la función de ésta dentro del nuevo sistema social.

2 En un análisis sobre el proceso de institucionalización del campo de las artes plásticas en Cuba, el sociólogo Alejandro Campos argumentaba:

En "Palabras a los Intelectuales" quedaron plasmadas las cuatro premisas en las que se apoyaría el sistema de afirmaciones y sanciones del Gobierno Revolucionario con respecto a la cultura. (...) Primero, la libertad de contenido sería permitida en tanto no implicara posiciones contrarias a la Revolución. (...) Segundo, el pueblo pasaría a ser considerado el receptor idóneo para la creación artística, quedando claramente manifestado que los esfuerzos de la dirigencia revolucionaria se concentrarían en lograr que el arte y la cultura en general pasaran a ser patrimonio de las masas. Tercero, de acuerdo a los parámetros de utilidad social propios de un país en Revolución, la función de la creación artística debía dirigirse a educar el gusto de quienes hasta ese momento no habían tenido acceso al arte y la cultura. Y cuarto, con el ánimo de garantizar que la actividad cultural tomara los caminos que la Revolución necesitaba, el campo de la cultura en pleno debía quedar supeditado a un órgano gubernamental especializado, el cual se desempeñaría como la máxima autoridad del orden cultural, orientando y estimulando cada uno de sus actos identitarios (CAMPOS, 1997: p.26-27).

3 De ello se desprende la absoluta marcación del régimen respecto a la vida del pueblo entendido éste como cuerpo total o masa colectiva, en detrimento del reconocimiento de derechos a la pluralidad y la diferencia de las subjetividades individuales-, de los hombres y mujeres que le conforman y cuya realidad queda definida por el Estado, garante en definitiva de los límites de esa realidad y del sentido mismo de realidad. El Estado entonces se convierte por decreto propio en el elemento central de la experiencia nacional, tanto en la esfera pública como en el ámbito privado; regula y administra toda existencia y condición de posibilidad, prescribe el deber ser del sujeto revolucionario y determina los contornos de la imaginación social.

4 Al margen del debate sobre política cultural y en torno a la función del nuevo arte revolucionario o la discusión estética sobre el lenguaje idóneo para el cine en tiempos de revolución que ha suscitado ese episodio de censura silenciado por décadas y recuperado recientemente por la historiografía y la crítica para reactivar las discusiones sobre las funciones del arte y los intelectuales, así como el papel de las instituciones culturales en una época de transformaciones sociales, económicas y políticas en la isla, lo que nos interesa rescatar aquí es algo que ha sido generalmente trivializado en esos discursos que se empeñaron en tildar a $P M$ como un filme menor carente de relevancia cinematográfica, desplazando la atención al acto de censura y la consiguiente polémica. Lo que deseamos comentar, sin embargo, compete al campo de la representación, al contenido mismo de las imágenes sobre las que se ejerce la operación punitiva.

5 Tomemos para ello el informe de la Comisión de Estudio y Clasificación de Películas del ICAIC que censuró el filme: 
[dicha comisión] reunida en sesión ordinaria acordó, después de estudiar la citada película, prohibir su exhibición, por ofrecer una pintura parcial de la vida nocturna habanera, que empobrece, desfigura y desvirtúa ${ }^{2}$ la actitud que mantiene el pueblo cubano contra los ataques arteros de la contrarrevolución a las órdenes del imperialismo yanqui (ICAIC, 1961: s.p.).

Lo que se atrevía a mostrar PM en 1961, el mismo año en que Fidel Castro declaraba el carácter socialista de la revolución cubana y su abrazo al marxismo-leninismo de mano de la Unión Soviética en una alianza estratégica frente a las agresiones militares y el bloqueo de Estados Unidos, era la imagen de una comunidad que pese a los tiempos convulsos intentaba vivir y normalizar su cotidianidad. A contracorriente del hieratismo realista socialista que pujaba por imponerse como modelo de representación desde la URSS para glorificar la masa estoica del pueblo en su lucha épica contra el enemigo en las trincheras y las fábricas; o del retrato colectivo y trascendental de trabajadores y soldados que simbolizaban la lucha contra el pasado burgués, $P M$ registraba la fiesta popular, una deriva por la noche habanera y los clubes y bares de enclaves periféricos de la ciudad como Regla y Marianao, o las zonas de Playa, Cuatro Caminos y el Puerto de La Habana. Un ejercicio espontáneo y caótico de free cimema que documentaba la promiscuidad de los cuerpos inmersos en el baile y los juegos de seducción, los cuerpos vibrantes en pleno disfrute y distensión, transgrediendo cualquier norma disciplinaria o ritual de contención formal por parte del Estado. En PM no aparecían los cuerpos uniformados de los milicianos revolucionarios, sino la vida y los afectos prodigados por esos mismos cuerpos cuando se quitan el uniforme y visten su individualidad fuera del discurso totalitario y grandilocuente de la Historia con mayúsculas y los relatos oficiales.

7 Cuerpos negros $-\mathrm{y}$ no negros- mezclados, de extracción humilde, que se mueven a golpe de tambor y percusión, de danzas y sonidos que resistieron a la barbarie de la colonización como signo de la memoria de la diáspora africana y forma de reconstrucción de identidades etno-raciales trasatlánticas en el sistema mundo moderno/colonial de género, que subsistieron a la violencia colonial y las políticas de blanqueamiento sobre las que se han edificado los relatos de la nación cubana. La censura de PM invisibiliza esos cuerpos, los silencia, deja sin voz y sin un espacio de enunciación a los descendientes de los griots, les arrebata sus tambores, sus poesías, sus cantos, sus narraciones, su lengua. Interrumpir la música y la danza, expulsar la fiesta negra de las pantallas, metaforiza la reinscripción de un tiempo de violencia epistémica en que los cuerpos negros fueron maniatados, privados de movimiento y libertad, esclavizados bajo la ideología racista de la empresa colonial. Si entonces el cuerpo negro fue un instrumento a doblegar en tanto fuerza de producción esclava, en el año 1961 se convertía en una presencia que debía encajar en la idea de igualdad del nuevo sistema social, un sujeto a adoctrinar y amoldar a los códigos ejemplarizantes de un "hombre nuevo" -integrado políticamente e ideológicamente centrado, militante comunista, heterosexual, laico, sometido a procesos de blanqueamiento cultural.

“...los tambores se habían dejado de oír con la intensidad de antaño, (...) múltiples costumbres y tradiciones (...) se fueron apagando en la medida en que el discurso oficial deslegitimaba la religión como un pensamiento infecundo" (MENÉNDEZ, 2017: p.249).

Desterrar de las pantallas esos cuerpos equivalía a una operación de ocultamiento de diferencias raciales y de clase persistentes durante siglos, mediante la que el emergente gobierno revolucionario trataba de extirpar artificialmente el racismo incubado en los 
imaginarios populares y las prácticas institucionales, como si el simple borrado de una imagen transformara con su ausencia la realidad social. Para el gobierno revolucionario cubano, amparado en una Constitución socialista que declaró la igualdad de todos los ciudadanos, el asunto del racismo y del problema racial en la isla ha sido permanentemente vetado en el debate público por la incomodidad que supone reconocer el fracaso de un modelo político que, pese a su discurso de promoción de un cambio social absoluto e irreversible, no ha logrado erradicar la colonialidad ${ }^{3}$.

En este texto nos aproximaremos a obras en vídeo producidas en el arte cubano contemporáneo entre los años 1997 y 2014. Estas imágenes en movimiento han situado el cuerpo masculino negro como protagonista de narraciones audiovisuales que interpelan los imaginarios del racismo popular e institucional e interrogan las huellas de la colonialidad en el presente insular. Son propuestas que han restituido la imagen de un sujeto racializado y subalternizado, que fue expulsado del espacio visivo de las pantallas con la censura del documental PM en 1961. Desde el silencio a través de los que esos hombres negros miran a cámara, estos relatos reivindican la presencia de los cuerpos afrodescendientes en tanto subjetividades atravesadas por las políticas disciplinarias y la violencia del Estado.

Las fantasías del proyecto nacional de refundar un sujeto político revolucionario y homogéneo, pasaban por el disciplinamiento mimético de ese otro racial, quien -con sus desbordes y excesos- ponía en "peligro" la frágil y urgida autoridad del discurso estatal. De ahí que, la lógica de invisibilizar el orden racializado que funda las bases de las dinámicas sociales y de las apuestas de ciudadanía de la Cuba postrevolución -por supuesto, amplificándose también a la contemporaneidad-, no ha hecho más que naturalizar las prácticas de dominación, exclusión y discriminación heredadas del período colonial (ARCE, 2015: p.63).

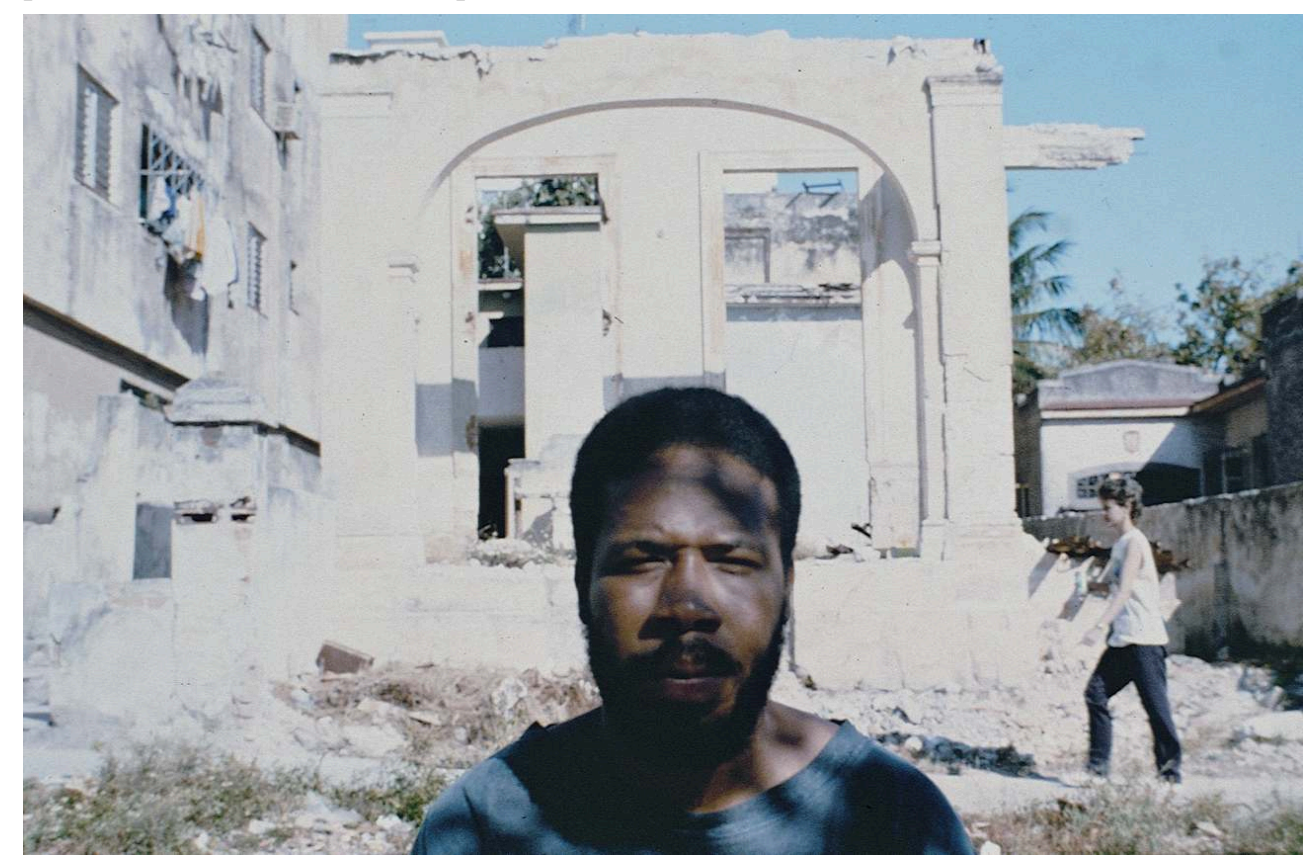

Carlos Garaicoa, Cuatro cubanos, 1997. Vídeo instalación, vídeo HI8 transferido a DVD, 8 min, dimensiones variables. Fotograma. Imagen cortesía del artista, Galleria Continua (San Gimignano, Les Moulins, Beijing, La Habana) y Galería Elba Benítez. 


\section{Lo que cuentan los cuerpos en silencio de los soldados.}

La guerra me tiene harto, me cago en mi condición heroica de dilecto hijo de la patria agradecida: prefiero ser el "jubilado", ancianito respetable; ¿qué coño tiene de malo? (...) ¿Estoy obligado a ser héroe toda mi vida y no cometer un solo lugar común que no sea de héroes; estoy obligado a sonreír a las nuevas generaciones desde una foto rígida mientras mi nombre cuelga de un CDR?

(ÁLVAREZ, 1997: p.129) ${ }^{4}$.

11 Al margen de la arenga oficial del Estado sobre la erradicación del racismo en la nueva sociedad, el factor etno-racial desempeñó un rol central en los discursos africanistas que sustentaron la mirada y las relaciones de Cuba con el continente africano, algo expresado abiertamente como parte de la política internacional del país desde la Conferencia Tricontinental en 1966 y que marcaría uno de los pasajes más extensos y desgarradores para miles de cuerpos que fueron uniformados y enviados a la guerra.

Entre 1975 y 1991, el gobierno cubano orquestó la campaña militar más larga, cruenta y costosa de su historia al intervenir en el conflicto fronterizo entre Angola y Sudáfrica y tomar parte junto al MPLA (Movimiento Popular para la Liberación de Angola) en la guerra civil angoleña frente al FNLA (Frente Nacional de Liberación de Angola) y la UNITA (Unión Nacional para la Independencia Total de Angola). El enfrentamiento entre estas tres formaciones anticoloniales y la intervención cubana en estas guerras, encarnarían la disputa polarizada de un orden mundial dividido entre los sistemas capitalista y socialista y la hegemonía de Estados Unidos y la Unión Soviética, que pujaban por la influencia económica, política e ideológica sobre los países del Tercer Mundo y los territorios africanos en proceso de descolonización.

Pese a la victoria de la coalición Cuba-URSS-MPLA frente a Sudáfrica, y al relato épico anticolonial, antimperialista, antiapartheid y africanista del gobierno cubano, los episodios de la contienda bélica y militar en Angola han sido escamoteados al debate público, la historiografía o la producción intelectual y artística y relegados a zonas de silencio. Pocas imágenes y testimonios han trascendido sobre esos hechos de la historia reciente cubana, si bien desde finales de los años ochenta han sido un tema explorado de manera recurrente por la literatura de ficción. El cine, por otra parte, ha incursionado en esos motivos desde una postura afín a las narraciones oficiales del Estado; teniendo en cuenta, además, que las pocas producciones realizadas hasta la fecha han estado auspiciadas por los Estudios Cinematográficos de la Fuerzas Armadas Revolucionarias, órgano que posiblemente tiene el control de la mayor parte del material de archivo clasificado sobre esos hechos. Además, hay que tener en cuenta que los corresponsales de prensa no pertenecían a órganos autónomos, sino que eran parte central de la propaganda revolucionaria.

14 En ese prolongado silencio institucional en torno a la reconstrucción de la memoria histórica y en un imaginario donde, paradójicamente, las imágenes están ausentes, el derecho a contar su experiencia, sustraído a miles de subjetividades que vivieron en carne propia el horror de la guerra o que fueron testigos directos o indirectos de su impacto, ha sido tal vez el mecanismo de obstrucción más coercitivo y efectivo para la invisibilización de las víctimas.

El vídeo Cuatro cubanos fue realizado en La Habana en el año 1997 por Carlos Garaicoa (La Habana, 1967) ${ }^{5}$. El propio artista define esta obra como "una entrevista en silencio, 
un testimonio sobre los horrores y el tabú del tema de la guerra" mantenido en el lapso de una década que había dejado sin resolver las deudas con las miles de personas, cuerpos y subjetividades atravesados por el dolor y el recuerdo. Esta pieza, una de las primeras en las que el artista emplea el medio videográfico, se mantiene apegada a una estética fotográfica a través de la que Garaicoa construye el retrato documental de Ariel, Morazen, El Zurdo y Bárbaro, cuatro jóvenes, pertenecientes a la generación del artista, que habían sido enviados a Angola a combatir.

En la pantalla aparecen inmóviles estos cuatro hombres, afrodescendientes, uno tras otro, mirando fijamente a la cámara, sin poder proyectar sus voces. Mientras tanto, en el fondo se ve el paisaje de La Habana en ruinas -destruida por la desidia, más que por las balas-, donde la vida cotidiana parece fluir con normalidad, con sus ruidos y vicisitudes habituales. Sin embargo, el primer plano de esta composición se convierte en una elegía al ostracismo, el desarraigo y la exclusión de estos cuatro ciudadanos que han sido expulsados de ese tiempo de la nación, de esa aparente normalidad. Vidas condenadas a habitar el tiempo de la memoria, el pasado en el que se rompieron los lazos con sus familiares y amigos, en que la guerra los empujo a la experiencia imborrable y cruel de una realidad paralela. Algo de lo que no se habla, que ha quedado en silencio, tal vez por la crudeza de las palabras que podrían dar cuenta de la brutalidad del conflicto bélico.

17 Es aquí donde la elección del vídeo en la trayectoria de un artista hasta entonces habituado al lenguaje de la fotografía deviene en una necesaria expansión del espacioimagen fotográfico. Solo el fondo de la pantalla, donde se percibe claramente la imagen en movimiento, junto al elemento sonoro, frente al hieratismo y el silencio de los sujetos retratados, permiten acentuar la violencia contenida de la escena. La relación con la memoria se potencia entonces en el tiempo congelado en que se hallan las figuras en primer plano. La imposibilidad de hablar, la clausura del discurso oral, la pérdida de la voz, no es resultado de los límites del medio audiovisual, sino de la pujanza del carácter solemne y de la ontología misma de la fotografía como medio vinculante con las políticas de la memoria y los usos sociales del género documental, que indefectiblemente intervienen aquí en la semiótica de la imagen mnémica.

...el cuerpo del soldado, rígido y erguido, respiraba conformidad y disciplina, y personificaba el modelo de masculinidad tradicional difundido por las estructuras militares.

...los cuerpos de los soldados que regresan de la guerra desgarrados, fragmentados constituyen una paradoja: esos hombres que han sobrevivido a la experiencia que (...) había de reafirmar su masculinidad, regresan menguados, castrados, rotos, inútiles. (...) el cuerpo del veterano que regresa de la guerra herido o mutilado no tiene carácter referencial. La no referencialidad de ese cuerpo se convierte en operativa durante la posguerra puesto que es entonces cuando dicho cuerpo adquiere sentido y se convierte en objeto de estrategias discursivas cuyo ámbito referencial ya no se limita al campo de batalla sino que se amplía a todo el contexto sociopolítico en el que nace dicho discurso sobre la guerra (ALSINA y BORRÁS, 2000: p.96-97).

18 A colación de la anterior cita, no debemos olvidar que la revolución cubana es un proceso que triunfa a través de la vía armada y que la arquitectura del régimen se ha construido sobre un signo oposicional de carácter bélico y militarizado. Hablamos de un sistema de gobernanza estrictamente masculinizado y basado en valores y estereotipos de masculinidad que definen el lenguaje disciplinario y totalitario del Estado sobre sus ciudadanos. ¿Qué simbolizan entonces los cuatro cuerpos de esos jóvenes cubanos que 
han regresado de la guerra y permanecen mudos ante la cámara? ¿Acaso callan por observar un código de conformidad y disciplina militar? ¿Por qué estos héroes no cuentan las hazañas de los combates y se regocijan en relatos de hombría y gloria consumada entre balas?

Refiriéndose a las representaciones de las memorias de la Guerra en Angola en la obra de la generación de escritores cubanos denominada los Novísimos -localizada entre los años ochenta y noventa-, el crítico literario Carlos Uxó explica:

...la participación cubana en Angola se aborda desde una perspectiva crítica, en la que se subraya no ya el posible beneficio social de la contienda sino la tragedia personal de los participantes, se insiste en la falta de apoyo mutuo entre los soldados (...) e incluso se pone en duda la tan repetida voluntariedad de su participación (...), se enfatizan los problemas de adaptación con los que han de enfrentarse los soldados al regreso -tanto por las heridas físicas como por las consecuencias psicológicas- así como el desaliento que sufren al retornar a un país en crisis (UXÓ, 2010: p.211).

Somos conscientes de los peligros que encarnan las imágenes como entidades frente al Estado, en tanto la imagen pone al descubierto la violencia de éste, se convierte en evidencia, documento, testimonio y objeto inicial. La imagen construye realidad allí donde la realidad misma intenta ocultarse o negarse. Las imágenes afectan los relatos oficiales porque ilustran o critican, crean una narración paralela que compite con los primeros en grado de verosimilitud. En ese sentido, el aura de la fotografía, tal y como la conocimos en un episteme pre-digital, se mantuvo apegada a nociones documentales que intervenían directamente en los sentidos de la memoria. Entonces, la ausencia de la fotografía mermaba la capacidad de recordar y de historiar; en cierto modo hacía inaccesible el acontecimiento histórico. No fotografiar o sustraer lo fotografiado del dominio público clausurándolo en el interior de los archivos y clasificando su contenido -como ha ocurrido en Cuba con las fotos y las filmaciones documentales de la guerra en Angola-, es por definición una gestión política de la memoria, un instrumento del poder que ha acompañado la evolución del medio fotográfico en el sistema mundo moderno colonial.

21 Ariel, Morazen, El Zurdo y Bárbaro, son apenas cuatro cubanos que sobrevivieron a otros miles cuyos rostros y recordatorio quedó limitado al marco diminuto de una foto carnet que acompañaba un osario en los funerales colectivos organizados por el Estado al repatriar los cuerpos de los caídos en combate en suelo africano ${ }^{6}$. Sin embargo, las víctimas del horror de la guerra no fueron todas sepultadas, vagan en el presente en un paisaje de trauma y amnesia donde los héroes de ayer malviven en una sociedad que les ignora, porque forman parte de un pasado de horror y despilfarro bélico en el que el orgullo de la nación se devoró a sí mismo para terminar recogiendo las migajas y miserias de la posguerra y el post-socialismo. El simbolismo poscolonial de millares de cuerpos negros regresando a África, enviados en un viaje de retorno -en muchos casos definitivo- al continente del que fueron arrancados sus ancestros, re-articulaba la violencia etno-racial del desplazamiento de la diáspora africana. Pero no se habla de eso ya que forma parte de la iconoclastia del Estado. En definitiva, es relativamente más fácil y menos incómodo silenciar los cuerpos de los que nunca tuvieron voz en el sistema mundo moderno/colonial de género ${ }^{7}$. 


\section{Coreografía en silencio: una performance radical del cuerpo negro como resistencia y acto de enunciación.}

En el año 2000 el fotógrafo Juan Carlos Alom (La Habana, 1964) rinde un homenaje a La Habana y a los cuerpos de los sujetos subalternizados y racializados que la habitan inventando estrategias de supervivencia al límite en una eternizada crisis. Habana Solo es un filme experimental rodado en $16 \mathrm{~mm}$ que reinscribe la deriva de PM por la geografía social de la ciudad y sus territorios más precarizados ${ }^{8}$. Influenciado por el énfasis narrativo del montaje del cine de vanguardia ruso, el free cinema y las películas documentales de experimentación de Nicolás Guillén Landrián en el ICAIC entre los años 60 y 70, Alom diagrama un contrapunteo entre la imagen y el sonido que invoca esas músicas y energías que no han podido ser clausuradas por la agonía de un contexto socioeconómico maltrecho y la desidia del tiempo sobre la arquitectura en ruinas de la capital ${ }^{9}$.

La película se estructura en una consecución de solos de destacados músicos cubanos mientras la cámara se mueve al ritmo de la banda sonora, recorriendo las calles de La Habana para mostrar la vida que discurre en ellas. No es baladí, y por el contrario sí harto elocuente, que el filme se inicie con la interpretación al piano del ciego Frank Emilio, evolucione con altibajos jazzísticos en las congas de Tata Güines y de otros músicos sucesivamente, y concluya con la danza silenciosa de un joven negro que desde la azotea de un edificio y con La Habana como telón de fondo ejecuta pasos de baile de la música popular que ha quedado en suspenso.

Volvamos al inicio del vídeo, a la primera secuencia en la que esa Habana en ruinas se hace omnipresente a través del lirismo fotográfico de Juan Carlos Alom, mientras los acordes al piano de Frank Emilio Flynn acompañan las imágenes que se suceden precipitadamente en la pantalla. Esa escena en la que el intérprete ciego se quita el reloj de pulsera y lo deja reposar sobre el piano antes de que le veamos ejecutar su solo, no puede desprender mayor simbolismo. Los primeros minutos del filme, que son una introducción -incluso antes de que aparezcan los créditos de la película-, enfatizan ese pliegue del tiempo en que nos sumerge el vídeo. El tiempo de Cuba, el tiempo del relato de la nación, no parece sincronizar con la performatividad de una agencia etno-racial que intenta sobrevivir a pie de calle, lejos de los escenarios gloriosos y de la retórica enardecida y rimbombante del Estado. Quizás, la ceguera del pianista deviene en un guiño poético en el que podríamos reconocer los mecanismos de ocultamiento e invisibilización urdidos para cubrir con un velo determinadas zonas de la realidad social que tensionan las narraciones del poder ${ }^{10}$.

Por ello, cuando después del crédito inicial del vídeo la cámara echa a rodar caóticamente por los barrios deprimidos de Centro Habana o La Habana Vieja; y vemos los cuerpos inmersos en perentorias rutinas de subsistencia, el repiqueteo de la percusión de Tata Güines nos devuelve a un tiempo de vida. El tiempo de la calle, de los espacios de transgresión, de las geografías alternativas que son territorio de cuerpos no normativos, cuerpos no blancos que se hacen visibles en esos lugares descentrados, al margen de las narraciones totalitarias del Estado. En esas vetustas arterias de la ciudad cuya arquitectura se sostiene en pie cual fantasma ajado de la colonia, los cuerpos deambulan, entran y salen de las casas y portan con ellos sus historias mínimas, que son también pequeños actos de resistencia cotidianos. A continuación, como si de un descenso a los infiernos se tratase, la imagen acompaña la bajada en un ascensor del 
músico Enrique Lazaga, que con el güiro describe el sonido chirriante de esa modernidad dislocada en la que se detuvo un día la ciudad. Mientras salimos de nuevo a la calle, el raspado del güiro se va perdiendo, hasta quedar ahogado por el silencio, una vez más el silencio. Un silencio que tiene color. Un silencio encarnado en un cuerpo negro.

La ausencia de sonido en el final del corto, donde una vez más la fiesta colectiva es ahogada, es sustituida en este caso por la performance en soledad del cuerpo masculino negro, totalmente vestido de blanco, como los Iyawó, los sacerdotes iniciados en la Regla de Ocha-Ifá o Santería. Quizás esta escena pletórica de resiliencia traduzca el repliegue de prácticas, rituales y expresiones de convivencia comunitaria que han tenido que permanecer constreñidas en el espacio privado, expulsadas de la esfera pública en un Estado donde aquellas cosmovisiones y formas litúrgicas asociadas a complejos rituales de antecedente africano (MENÉNDEZ, 2017: p.252) y otros elementos constitutivos de la memoria de la diáspora africana entraban en contradicción con la ideología marxista-leninista y con el rictus grave que se demandaba de esa entidad abstracta denominada "pueblo cubano".

Otra vez el cuerpo que baila y celebra pone en evidencia la pujanza de la colonialidad en aquellos estereotipos que durante el siglo XIX fijaron la imagen de un sujeto subalterno racializado bajo el nominativo negro a través de la marginalización cultural y el racismo sobre los afrodescendientes, así como su desplazamiento hacia zonas «laterales» y de subalternidad en las narrativas de la nación, donde determinadas tendencias modernas en el pensamiento político y social identificaron la idea de cultura y nación bajo una interpretación étnica que privilegiaba el origen blanco e hispano de lo cubano o mostraban un esfuerzo de blanqueamiento tras los conceptos de mestizaje $^{11}$.

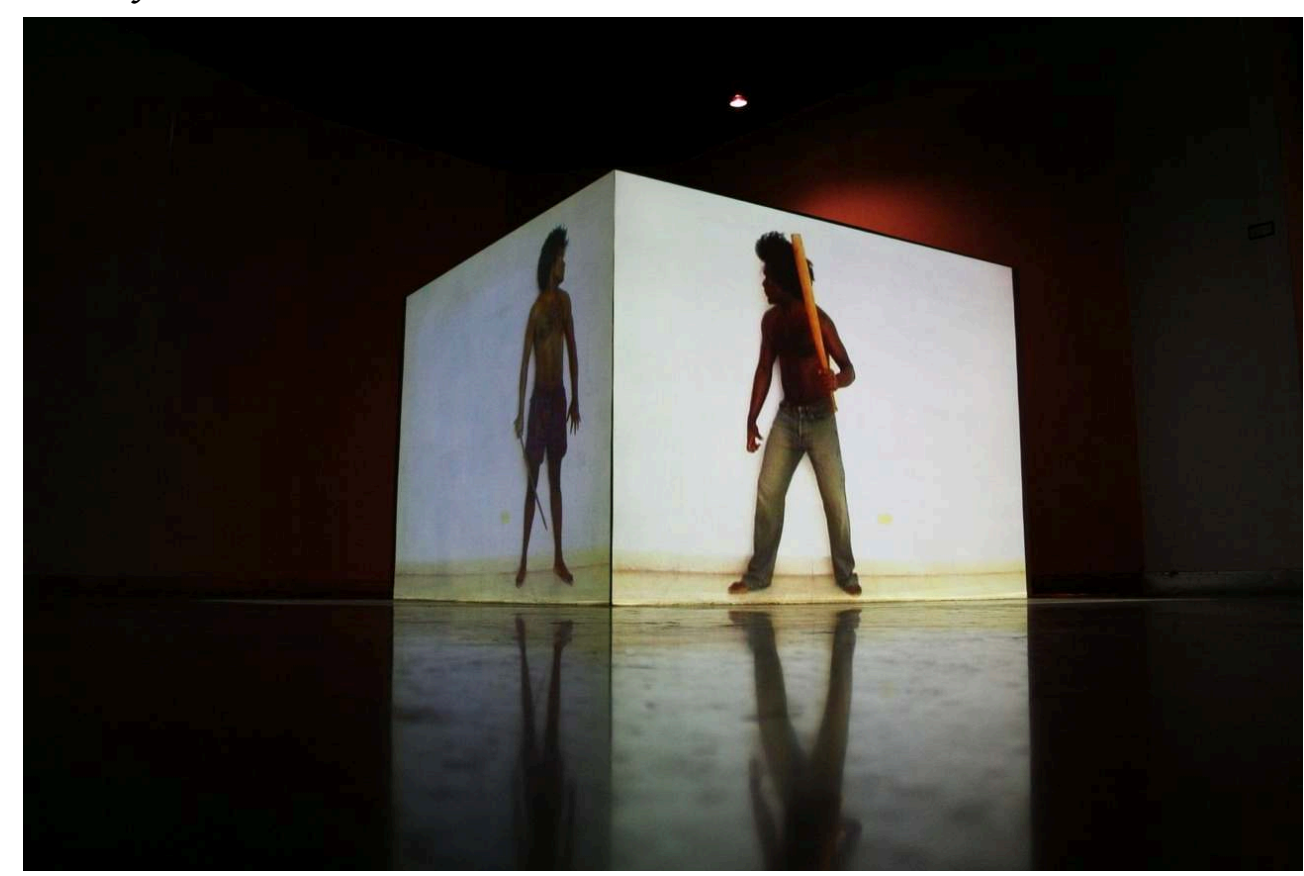

Alexandre Arrechea, White Corner, 2006. Vídeo instalación, 2 canales, 190 x 220 cm cada proyección. Imagen cortesía del artista. 


\section{Un silencio que no puede borrar las marcas de la opresión y el racismo sobre el cuerpo negro.}

Son precisamente esos estereotipos los que van a ser interrogados en 2006 en la vídeo instalación White Corner de Alexandre Arrechea (Trinidad, 1970), y en Pellejo, un vídeo fechado en 2013 por el colectivo Los Carpinteros ${ }^{12}$. En ambos casos, los estigmas de la colonialidad eugenésica revelan las ideas que han descrito al cuerpo del hombre negro como una masculinidad amenazante para la normatividad hetero-patriarcal blanca: instintivo, emocionalmente primario, hipersexualizado, vago, irracional, salvaje, animal, inferior..., son adjetivos que hacen explícita la construcción del cuerpo negro como objeto del racismo. En estas dos obras, la masculinidad del sujeto negro es reflejo de históricos procesos de discriminación donde los atributos del mito viril han sido hipertrofiados. Desde la esquina en que la mirada blanca se sitúa para enjuiciar al hombre negro, el arresto, la violencia o la valentía que en el sujeto masculino blanco occidental crea la imagen del héroe valeroso donde el enfrentamiento en la batalla deviene signo de orgullo nacional; aquí son invertidos bajo la axiología euroblanca y criolla que criminaliza a las subjetividades afrodescendientes en un espectro de conductas marcadas por la coerción biopolítica. La pose acechante y sigilosa del propio artista Alexandre Arrechea, auto-representado en el vídeo, traza una peculiar genealogía de la estigmatización del sujeto afrodescendiente objetivado en una mirada donde la idea de raza perfila el retrato de una identidad conflictiva, encarnación del miedo colonial al otro que evoluciona desde las primeras figuras de los cimarrones en el siglo XIX ${ }^{13}$.

La estrategia de auto-representación por parte del artista podría funcionar en esta obra en tanto interpelación al legado visual de una Historia del Arte que ha excluido la representación de los afrodescendientes. La excepción serían aquellas imágenes cargadas de violencia y de una mirada incriminatoria sobre el cuerpo negro dentro de la pintura y el grabado coloniales, $\mathrm{u}$ otras representaciones insertas en la lógica etnográfica de las ciencias naturales y sociales, habituales en la fotografía de finales del siglo XIX y principios del XX. Basta repasar los textos del primer Fernando Ortiz influido todavía por la escuela de Cesare Lombroso para advertir el calado de la criminología positivista en los estudios de etnología criminal del antropólogo cubano, en los que se seguían las ideas lombrosianas sobre el determinismo étnico de la criminalidad.

La raza negra es la que bajo muchos aspectos ha conseguido marcar característicamente la mala vida cubana, comunicándole sus supersticiones, sus organizaciones, sus lenguajes, sus danzas, etc., y son hijos legítimos suyos la brujería y el ñañiguismo, que tanto significan todavía en el hampa de Cuba, como significaron en su época los negros curros, hoy curiosos tipos de arqueología criminal cubana (ORTIZ, 1916: p.12-13).

31 Todavía en nuestros días, lamentablemente, resulta demasiado frecuente y rutinaria la práctica racista institucional y el abuso de poder en las calles de las ciudades cubanas, donde se repiten escenas de violencia autoritaria sobre los cuerpos negros. Es habitual ver a la policía acosando y exigiendo identificación a hombres y mujeres afrodescendientes, a quienes incluso se les llega a registrar bolsos y pertenencias, presuponiendo que son delincuentes y sin que medie previamente la comisión de algún delito. A esto se suma el instrumento represor que constituye la de nominada Ley de 
Peligrosidad, cuya aplicación habilita la detención y reclusión de un sujeto sin que el mismo hubiese incurrido en un acto delictivo, deviniendo en una flagrante violación de los derechos humanos (MARTÍNEZ, 2009: párr. 27).

El cuerpo en tensión del hombre negro blandiendo un arma, los músculos contraídos y la respiración agitada que anuncian la inminente lucha, el sonido hondo semejante al de una válvula de presión que alivia la temperatura acumulada. Todo en la escena revela un clímax a punto del estallido. Por si fuera poco, el torso desnudo y los pies descalzos remiten indefectiblemente a esa iconografía cimarrona legada por los imaginarios de la colonialidad. "El negro es un objeto fobógeno, anxiógeno" (FANON, 2009: p.139).

Pero tal vez el elemento más interesante en esta pieza resida en la duplicidad especular de la imagen del cuerpo masculino negro: esa figura que encarna el signo de una violencia mítica y atávica en las construcciones racistas de la modernidad blanca y criolla. Si por una parte White Corner nos sitúa críticamente ante la discursividad normativa que describe al cuerpo no blanco a través de la negrofobia (FANON, p.144); por otro lado parece convocar la teoría lacaniana del estadio del espejo para significar el despertar de una consciencia racial en el hombre negro. Quizás el enfrentamiento de esas anatomías especulares diagrama la noción escindida del propio cuerpo masculino negro como un sujeto diferente, al que le es imposible reconocer en sí mismo esos estereotipos con los que se le ha cosificado y patologizado. La imagen proyectada a cada lado de la pantalla como arquetipo de virilidad exacerbada que rezuma terror y despierta el miedo en el otro, es en sí misma una imagen que de una esquina a otra de la pantalla redunda en un profundo sentido de extrañamiento ${ }^{14}$.

Por otra parte, en Pellejo aquellos estereotipos de virilidad que han encorsetado el cuerpo negro como objeto de deseo o temible encarnación de un depredador sexual patológico, conllevan una retórica en la que cuerpo y sexo masculino son sublimados. En ese sentido, la apología de la masculinidad ha instrumentado el poder del falo como estructura normativa del machismo y la heterosexualidad dentro de la sociedad cubana, alimentando hasta el presente los imaginarios de la colonialidad que permean los discursos sexuales en relación con el cuerpo negro. Voracidad incontrolable, lascivia, falta de pudor, violencia, violación, son los subtextos que rodean la mitología fálica del cuerpo negro. En este vídeo que bascula entre el lirismo exquisito del tratamiento fotográfico y la sobre-exposición casi pornográfica de los personajes ante la cámara, el tiempo de la nación es condensado en el tiempo vital de una pareja que copula desde la adolescencia hasta la vejez.

La pieza arranca con el cierre de una ventana que clausura los cuerpos jóvenes, vigorosos y deseantes de dos adolescentes en el interior doméstico de cualquier solar habanero, dejándoles al margen del tiempo histórico de la nación. Y termina cuando el hombre ya anciano y agotado, con las marcas y cicatrices de la edad en su anatomía, abandona el lecho y vuelve a abrir la ventana a través de la cual penetra el ruido de la calle; mientras tanto, él se gira en silencio para mirar la cama que ha quedado vacía dejándole a solas una vez más. El cuerpo de la mujer, de la amada, no yace más sobre las sábanas blancas, ha desaparecido. Esos sonidos diegéticos de la urbe que inundan la habitación estuvieron siempre ahí, como una cacofonía impuesta sobre los cuerpos que anhelaban moverse con un ritmo propio. Por momentos, en medio del frenesí del sexo, el bullicio externo parecía quedar ahogado por el jadeo de los amantes y el traqueteo de la vieja cama. Sin embargo, el murmullo de la calle persistía en imponerse sobre los 
cuerpos en tanto recordatorio y advertencia de una colonialidad que mantiene secuestrada la masculinidad afrodescendiente a través de la representación de una fantasía de la sexualidad hipertrofiada.

¿Qué supone entonces la presencia de ese cuerpo negro individual en la organización de un Estado que se ha definido a sí mismo en el relato de la nación como figura de poder con signo eminentemente masculino y blanco? Basta un repaso a las imágenes legadas por la fotografía épica de los años 60 y 70 para comprobar cómo el cuerpo negro fue transformado en sujeto colectivo, masa trabajadora o combatiente integrada en la epopeya del cambio social, quedando invisible su subjetividad tras la euforia de la igualdad -equivalente a un tipo de blanqueamiento ideologizado- proclamada como base del emergente sistema social. Esa narración fotográfica que entroniza la propaganda política del régimen autoritario cubano destaca tan solo la efigie del héroe, del líder cuya masculinidad debe imponerse a todos y sobre todo. En ese sentido, inevitablemente cualquier representación masculina diferencial entraña una competencia que hay que minimizar. De ahí que la virilidad del hombre negro se neutralice por medio de su disolución dentro de la masa en la esfera pública; o que cuando se le señale como individuo vuelvan a aflorar los estereotipos impresos en la colonialidad del imaginario popular e institucional cubano, convirtiéndose esos caracteres masculinos en una proyección fuera de la normatividad social.

La masculinidad se sostiene en el no cuestionamiento de sí, de las normas y de los ideales grupales (los de la masculinidad incluidos), en el estar contenido en una estructura y en la obediencia a la autoridad o a una causa, obligándose a sacrificar lo propio con la ilusión (casi siempre incumplida) de que algún día el varón será dueño de sí (o al menos de alguien/algo). Lo deseado/temido es, desde esta creencia, pertenecer/ no pertenecer a un grupo (de varones), ya que ellos (...) son los que avalan con su aplauso la masculinidad. (Marques y Osborne, 1991, citado en BONINO, 2000: p.49)

Fuera de esa habitación en la que el cuerpo del hombre negro ha envejecido nada parece haber cambiado, la vida de los afrodescendientes en Cuba continúa atrapada en una inmovilidad que replica el propio tiempo congelado de una nación que aguarda entre bostezos por una transición que nunca llega y que no necesariamente va a mejorar las condiciones en las que habitan los sectores más vulnerables de la sociedad. 


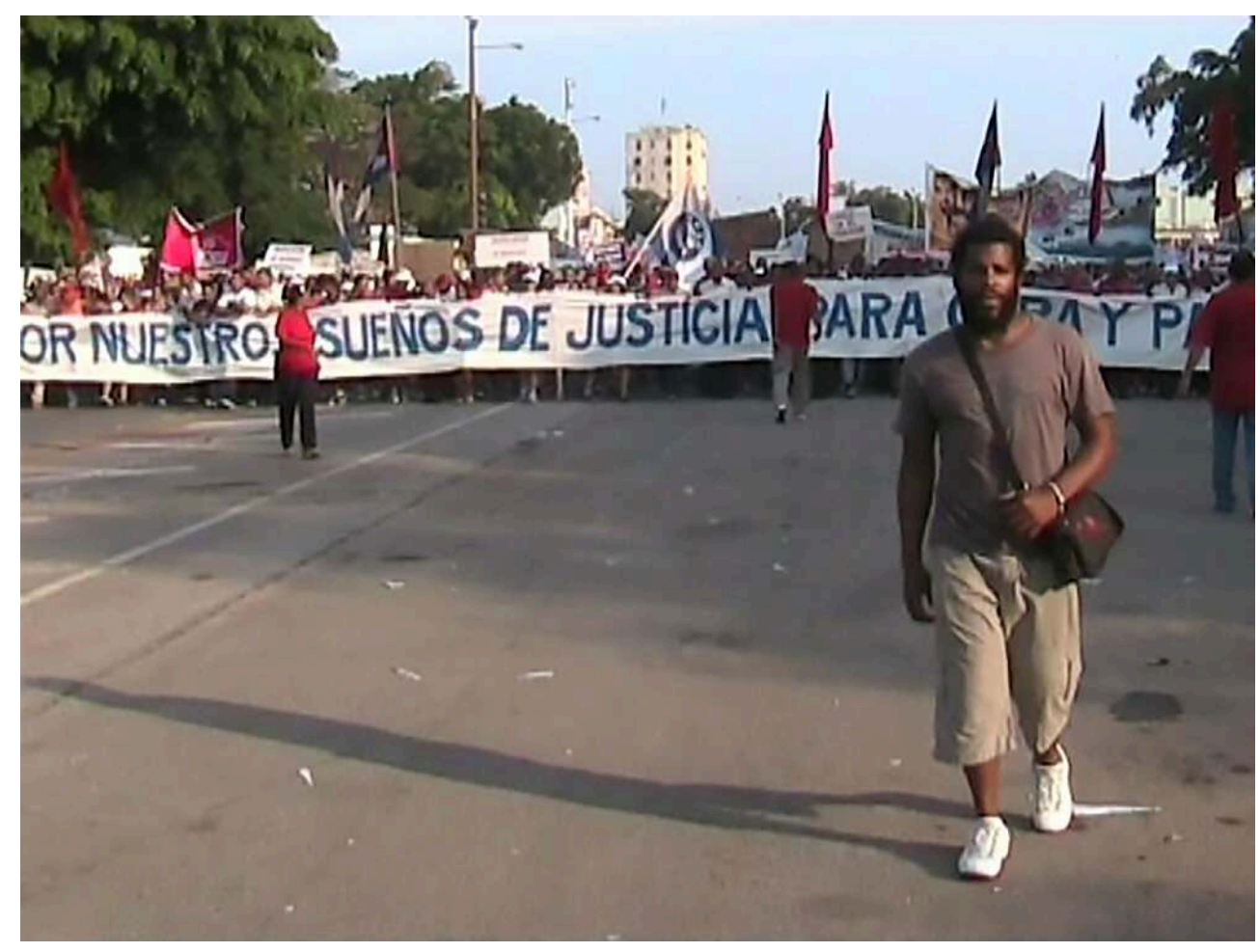

Raychel Carrión, Fallas de origen, 2008. Vídeo performance, 16 min 54 s. Imagen cortesía del artista.

\section{Cuerpos a contratiempo: el tiempo de silencio de los excluidos.}

¿Qué sucede cuando ese cuerpo negro se sale de la masa, rompe el esquema de la totalidad y reivindica su diferencia? Durante el desfile del $1^{\circ}$ de mayo de 2007, el artista Raychel Carrión (La Habana, 1978) se unió a la marcha multitudinaria que cada año se organiza como demostración pública de la capacidad de la revolución de movilizar al pueblo cubano, aun cuando gran parte de los convocados cumplen con desgano con un simulacro de consenso obligado por temor a las represalias del Estado. La performance consistió en andar junto al pueblo trabajador, pero a un ritmo diferente, ralentizado, que metaforizaba a través de la sutileza de la mínima intervención el desfasaje entre colectividad e individuo, entre discurso oficial y subjetividad, en un contexto donde la arenga gubernamental repite obstinada y ciegamente la idea de igualdad. Los movimientos exageradamente lentos del artista emulaban la propia torpeza del sistema para reciclar sus estructuras de funcionamiento, al tiempo que tal vez metaforizaban la escasa movilidad social que los y las afrodescendientes han tenido en más de medio de siglo de socialismo en Cuba. La marcha ágil del grupo era confrontada en Fallas de origen $^{15}$ por el contrastado paso entre el pueblo y el artista, entre los trabajadores y el intelectual, poniéndose el dedo sobre la llaga: qué celebran estos trabajadores cuyo empleo precario y las dificultades de acceso a los bienes más primarios son la espada de Damocles de la maltrecha economía nacional; qué tipo de perversa operación populista obliga a quienes más padecen la crisis a festejar el propio régimen que les condena a la miseria; qué lugar ocupa el vaticinado intelectual orgánico gramsciano en una sociedad cuyas relaciones de poder han censurado la función esencial del pensamiento crítico. 
En esta acción documentada en el vídeo Fallas de origen, el silencio histriónico del hombre negro, que es a la vez el mutismo del intelectual, contrasta con la euforia y los gritos del pueblo trabajador. El cuerpo que marcha solo y en silencio se enfrenta a la masa enardecida y ensordecedora que avanza a paso rápido siguiendo disciplinadamente la coreografía ensayada tantas veces como parte de la puesta en escena totalitaria. El encuentro de uno y otros en la pantalla sintetiza las fricciones en el relato nacional. El punto más dramático de la narración videográfica es el momento en el que la policía saca literalmente al artista del plano, expulsándole del campo visual. El fuera de campo entonces re-articula la operación de censura sobre la imagen del cuerpo negro que ya veíamos en $P M$.

Hemos mencionado hasta ahora algunos documentos y ficciones donde el cuerpo masculino negro es ubicado en los márgenes de la colectividad, de la masa, del espacio público, de la idea de nación. No obstante, permanecía inscrito en la geografía física y simbólica de la isla. A contracorriente, en Polaris, un vídeo de 2014 de Los Carpinteros, un hombre solitario atraviesa con mucho esfuerzo los Pirineos llevando a cuesta un pesado fardo ${ }^{16}$. Lejos del cálido trópico de la isla, ya no se escucha el ruido de las calles de La Habana, solo el sonido hondo de la ventisca y el fatigoso peregrinaje a través de la nieve. Ese viaje que es el del exilio de millones de cubanos que también han sido escupidos del tiempo de la nación, tal vez es la metáfora heterotópica que imagina un lugar otro de libertad. La imagen narrada concluye cuando el hombre negro sitúa su tumbadora en lo alto de la montaña, dominando todo el paisaje, y del instrumento vuelve a brotar el repiqueteo de la percusión, que es la voz de la memoria y la resistencia del griot, el grito del negro, cuando la agencia afrodescendiente encarna su voz.

Este vídeo de Los Carpinteros posiblemente no pueda desligarse de una serie de obras en la que el colectivo ha trabajado durante varios años, que ha resultado en un sugerente conjunto de esculturas que representan instrumentos musicales derretidos. La condición metafórica de esos objetos que se han desvanecido por una continuada presión, que han perdido su forma y funcionalidad debido al excesivo calor, aluden de manera poética a una situación social de alta temperatura, a una prolongada exposición de esas entidades -entiéndase "cuerpos"- a un régimen de coerción que acaba anulándolos. La pérdida de corporeidad, o solidez en este caso, por una lado inhabilita a esos instrumentos para el ejercicio de su función, pero también conlleva la transformación de un cuerpo físico, el devenir de un estado caótico, desordenado, anormativo.

\section{Conclusiones.}

En una de las escenas de PM las manos de un hombre negro percutiendo sobre una tumbadora rompían el murmullo de la noche y convertían el encuentro de los cuerpos en fiesta, música y danza. Casi cuarenta años después, Habana Solo desplazaba la mirada de la ciudad en ruinas hacia los cuerpos negros que la habitan a través del toque cimarrón de Tata Güines. Ese sonido inconfundible de los tambores llegados de África recorre en la obra de Juan Carlos Alom las calles en rebeldía, como una energía inagotable que alimenta la resistencia del hombre negro. $Y$ es justamente ese toque interrumpido con la censura de $P M$ el que vuelve a "rugir su tigritud" ${ }^{17}$ en la escena final de Polaris. 
El cuerpo negro se convierte en estas obras en territorio de análisis crítico, inscrito de manera endeble en las narraciones de la nación desde el siglo XVIII e invisibilizado tras la utopía de la democracia racial con el triunfo revolucionario. En estos vídeos el sujeto masculino negro renuncia a la colectividad, o ha sido privado de una vida en comunidad. Aislado, solo, en la intimidad del espacio privado, su interpelación a la cámara refrenda el procedimiento de exclusión. Si por un lado el silencio a través del cual los rostros de estos hombres nos miran desde la pantalla describe el mecanismo de obliteración por el que sus voces han sido secuestradas en el relato totalitario de la nación; por otra parte, la ausencia de un registro de enunciación oral da cuenta de la propia presión heredada por las construcciones culturales de los atributos de la masculinidad axiomática: el hombre-hombre, en sentido machista, no habla sino que actúa, demuestra su valor por medio de la acción transformadora y de la dominación que encuentra expresión en las pulsiones fálicas y el comportamiento violento dentro del colectivo a través de la guerra y el enfrentamiento cuerpo a cuerpo, o en el ámbito privado en el encuentro sexual.

Si en $P M$ la censura, en tanto operación de silenciamiento, privaba a los cuerpos afrodescendientes de la celebración y la festividad inscritas en la genealogía de las formas de resistencia que emergieron desde el espacio de la plantación colonial como mecanismos de restitución colectiva de la memoria de la diáspora africana, en estos vídeos de artistas contemporáneos la performatividad del cuerpo masculino negro, que mira retadoramente a la cámara y convoca la atención de los espectadores a través del silencio, se transforma en denuncia de los regímenes de discursividad hegemónicos mantenidos por el Estado cubano tras el triunfo revolucionario de 1959, donde el racismo ha permanecido velado tras la utopía de una supuesta democracia racial. La presencia imponente y desacralizadora de ese cuerpo solo, aislado y apartado de la masa, de un sujeto no replicante que prefiere callar antes que repetir las consignas vacías de una falacia igualitaria y totalitaria, es una respuesta crítica al borrado institucional, habla por medio del cuerpo que llena el primer plano en la pantalla. El silencio en los vídeos de estos jóvenes artistas reinscribe esa violencia fundacional del Estado socialista, como una interpelación de los significados del acto punitivo de acallar la voz popular en esas prácticas colectivas de performatividad social, así como sus múltiples dimensiones simbólicas. ¿Acaso hay imagen más inquietante que la de ese joven que baila una melodía que no escuchamos en el paisaje ruinoso de la ciudad en la escena final de Habana Solo? ¿Es el silencio lo que escuchamos o somos nosotros los que no oímos el grito mudo?

\section{BIBLIOGRAFÍA}

ALSINA, C. y BORRÁS, L. (2000), "Masculinidad y violencia”, en Nuevas masculinidades, Icaria, Barcelona.

ÁLVAREZ, Alejandro (1997), Cañón de retrocarga, Ediciones Unión, La Habana. 
ARCE, Yissel (2016), "Relatos de exclusión. Indagaciones poscoloniales sobre raza y marginalidad en el cine de Sara Gómez”, en Arte y Políticas de Identidad, 13, 79-98, URL: https://doi.org/

$10.6018 / 250901$

BONINO, Luis (2000), “Varones, género y salud mental: deconstruyendo la «normalidad» masculina”, en Nuevas masculinidades, Icaria, Barcelona.

CAMPOS, Alejandro (1997), Viaje a la semilla: Institucionalización del campo de las artes plásticas en Cuba. 1976-1986, Trabajo de Diploma, Licenciatura en Sociología, Facultad de Filosofía, Historia y Sociología, Universidad de La Habana, La Habana.

CARBONELL, Walterio (1961), Crítica: Cómo surgió la cultura nacional, Ediciones Yaka, La Habana.

CARBONELL, Walterio (2005), Cómo surgió la cultura nacional, Biblioteca Nacional José Martí, La Habana.

CASTRO, Fidel (1961), Discurso pronunciado por el comandante Fidel Castro Ruz, Primer Ministro del Gobierno Revolucionario y Secretario del PURSC, como conclusión de las reuniones con los intelectuales cubanos, efectuadas en la Biblioteca Nacional el 16, 23 y 30 de junio de 1961, Departamento de Versiones Taquigráficas del Gobierno Revolucionario, URL: http://www.cuba.cu/gobierno/discursos/1961/ esp/f300661e.html

FANON, Frantz (2009), Piel negra, máscaras blancas, Akal, Madrid.

GARAICOA, Carlos (s.a.), Statement, inédito.

ICAIC (1961), Acuerdo del ICAIC sobre la prohibición del film P.M., ICAIC, La Habana.

LACAN, Jacques (1964-1965), “Clase 12 del 17 de marzo de 1965”, en El seminario, libro 12: Problemas cruciales para el psicoanálisis, URL: https://www.lacanterafreudiana.com.ar/2.1.5.1\%20CLASE\%201\%20S12.pdf

MARTÍNEZ, Iván César (2009), “El racismo en Cuba: una contribución al debate”, en Cubanálisis, URL: http://www.cubanalisis.com/ARTÍCULOS/IVÁN\%20CÉSAR\%20\%20EL\%20RACISMO\%20EN\%20CUBA.htm

MENÉNDEZ, Lázara (2017), Para amanecer mañana, hay que dormir esta noche. Universos religiosos cubanos de antecedente africano: procesos, situaciones problémicas, expresiones artísticas, Editorial UH, La Habana.

ORTIZ, Fernando (1916), Hampa afro-cubana: Los negros esclavos. Estudio sociológico y de derecho público, Revista Bimestre Cubana, La Habana.

UXÓ, Carlos (2011), Representaciones del personaje del negro en la narrativa cubana. Una perspectiva desde los estudios subalternos, Verbum, Madrid.

\section{NOTAS FINALES}

1. Puede verse el cortometraje documental $P M$ en el siguiente enlace, URL: https:// www.youtube.com/watch?v=QKvbUeqPYlo\&ab_channel=tuyomasyo

2.

Las cursivas corresponden a la autora para enfatizar la marcación axiológica del texto citado. Para profundizar en la polémica y el enfrentamiento sostenido entre determinados sectores intelectuales y el gobierno cubano respecto al filme, véase: JIMENEZ LEAL, O. y ZAYAS, M. Coords. (2012), El caso PM: Cine, poder y censura, Colibrí, Madrid. 
3. El ambiente de tensión en el campo intelectual generado por la censura del documental PM, coincide con la polémica suscitada por la publicación, también en 1961, del libro Crítica: Cómo surgió la cultura nacional, de Walterio Carbonell (Jiguaní, 1920 - La Habana, 2008). En este ensayo de corte marxista, a contracorriente de la historiografía tradicional, el historiador afrodescendiente trataba de revisar la historia de Cuba de los siglos XIX y XX, poniendo en evidencia el carácter esclavista y racista de la sacarocracia criolla, legitimada como protagonista de la gesta independentista contra el poder colonial español en las lecturas de reconocidos historiadores como Ramiro Guerra. Carbonell ponía el acento sobre el desplazamiento hacia posiciones secundarias y de escasa visibilidad que esos relatos blanqueados, de ideología burguesa, habían construido en torno al papel determinante de los esclavos africanos y afrodescendientes en el proceso revolucionario y la formación de la nación a través de la lucha de clases. Al mismo tiempo, advertía de la continuidad ideológica y la colonialidad de esas narraciones después de 1959, donde con sucesivas estrategias de blanqueamiento continuaban resaltándose los valores culturales de las clases dominantes del pasado. El libro fue retirado de circulación y no se volvió a imprimir hasta 2005, en una edición corregida cuyo título elimina el término Crítica y con una nota preliminar que no aclara en absoluto los avatares y censuras que padecieron el texto y Walterio Carbonell durante décadas. Junto a otros intelectuales que trataron de insertar en la agenda política y social del naciente gobierno cubano el problema del racismo, el autor sufrió el ostracismo dentro del régimen, siendo detenido en varias ocasiones hacia finales de los años sesenta, lo que incluyó su reclusión en instituciones de salud mental.

4. Esta obra fue Premio David de Novela de la UNEAC (Unión Nacional de Escritores y Artistas de Cuba) en 1989, aunque no fue editada hasta 1997; reeditada en el año 2012 y presentada en la Feria Internacional del Libro de La Habana en 2013, que contó con la participación de Angola como país invitado. Como otros libros de ficción y no ficción que abordan las memorias cubanas de las guerras en África, ha sido azarosa la suerte corrida por los manuscritos, llegando muy pocos de ellos a publicarse dentro de Cuba.

CDR son las siglas de los Comités de Defensa de la Revolución.

5. Carlos Garaicoa, Cuatro cubanos, 1997, vídeo instalación, vídeo HI8 transferido a DVD, 8 min., dimensiones variables.

6. La institucionalización y monumentalización del luto en funerales colectivos a través de lo que se llamó Operación Tributo, pretendió cerrar de modo épico el relato oficial sobre la participación de Cuba en diferentes misiones internacionalistas y campañas bélicas en distintas regiones del entonces denominado Tercer Mundo, en su mayoría en África, en lugares como Angola, el Congo, Namibia, Guinea Bissau o Etiopía. Las cifras manejadas por el gobierno cuentan aproximadamente 2.289 bajas entre el personal militar y 204 entre los trabajadores civiles que acompañaban a las tropas cubanas. Sin embargo, otras fuentes ajenas a la historiografía oficial hablan de un número de más de 10.000 muertos. Durante todo un día se extendió la vigilia nacional por los combatientes caídos, la víspera del 7 de diciembre de 1989, fecha coincidente con el aniversario 93 de la muerte del Titán de Bronce, Antonio Maceo, General y Jefe Militar del Ejercito Libertador de Cuba en la Guerra de Independencia contra el dominio colonial español. Ese día se efectuó el sepelio de los mártires de las contiendas armadas en África en todos los cementerios cubanos; mientras en el Parque Nacional Monumento del Cacahual, se realizó la conmemoración central con un discurso de Fidel Castro, en presencia del Presidente de Angola, José Eduardo dos Santos. Cada féretro u osario fue identificado con una pequeña foto carnet.

7. A ese silencio estructural que prevalece sobre los imaginarios de las guerras cubano-africanas, hay que sumar el tabú sobre el debate público en torno al VIH en Cuba, ya que los primeros casos de contagio del virus se verifican precisamente en combatientes que regresaron de la guerras en África.

8. Juan Carlos Alom, Habana Solo, 2000, Película 16mm transferida a DVD, B/N, 14 min 46 s. http:// juancarlosalom.com/films.html 
9. Aunque no podamos detenernos en un análisis sobre la obra de estos realizadores, resulta imprescindible mencionar el trabajo de dos cineastas como Nicolás Guillén Landrián (Camagüey, 1938 - Miami, 2003) y Sara Gómez (La Habana, 1942-1974), en tanto exponentes principales de un cine crítico que situó en primer plano una mirada sobre el racismo estructural persistente en la cambiante sociedad cubana de los años 60 y 70. Desde el lenguaje documental, fundamentalmente, ambos directores supieron interpelar a sujetos de a pie mediante la inquisidora perspectiva sociológica de una cámara que reflejaba las tensiones entre las expectativas y las incertidumbres experimentadas por masas anónimas de población ante las transformaciones del proceso revolucionario. Desde el ICAIC, centro neurálgico de la propaganda del Estado, y a través de un lenguaje en incesante exploración y renovación estética, permeado por las construcciones de la imagen fílmica de movimientos como la Nueva Ola Francesa, el Neorrealismo Italiano, el Free Cinema o el Cinema Verité, ambos creadores -también golpeados ellos mismos por la censura, el silencio y el racismo-, produjeron un cine de profundo calado artístico y una inteligencia irreverente que ha dejado una huella importante en las siguientes generaciones de documentalistas. En el caso de Juan Carlos Alom es evidente la deuda de sus fotografías y películas con Guillén Landrián; mientras que un joven artista como Javier Castro ha explotado de modo sencillo y sin demasiada edición la urgencia de un método directo como la encuesta documental tan brillantemente ensayado por Sara Gómez. Sobre estos directores emblemáticos, véase: RAMOS, J. y ROBBINS, D. Eds. (2019), Guillén Landrián o el desconcierto filmico, Almenara, Leiden; y ARCE, Yissel (2016), "Relatos de exclusión. Indagaciones poscoloniales sobre raza y marginalidad en el cine de Sara Gómez", en Arte y Políticas de Identidad, 13, 79-98, URL: https://doi.org/10.6018/250901

10. El tiempo histórico colectivo de la nación se narra a través de documentos depositados en archivos institucionales, monumentos, la escritura de la Historia con mayúsculas; la marcha pautada, marcial y reglamentaria de la parafernalia del Estado y todas sus escenificaciones en el espacio público a modo de desfiles y ceremonias totalitarias. Por contraste, el tiempo personal y privado de las subjetividades atravesadas y violentadas por ese tiempo histórico nacional, es casi un susurro o un rumor que circula de puerta en puerta, colándose en los hogares y construyéndose de las memorias privadas, familiares, comunales; tiempos de secretos compartidos, recuerdos guardados y recuperados, infracciones y disensos. Este tiempo de las historias mínimas y las vidas encarnadas en cuerpos diversos discurre en los intervalos de pequeñas liturgias cotidianas. Véase: VAN ALPHEN, Ernst (2009), "Hacia una nueva historiografía: Péter Forgács y la estética de la temporalidad”, en Estudios Visuales, 6, 30-47, URL: https:// openaccess.leidenuniv.nl/bitstream/handle/1887/14982/aa-Estudios\%20visuales.pdf?sequence=1 11. Un minucioso análisis de la voluntad de resistencia escenificada a través de las congas y comparsas de esclavos y libertos organizados en los cabildos de nación, que salían a la calle para celebrar el Día de Reyes durante el periodo colonial; así como su transformación a inicios del siglo XX en agrupaciones de música y danza constituidas en los barrios más pobres, y las continuas estigmatizaciones y prohibiciones que pesaron sobre estas expresiones de la cultura afrocubana en el espacio público, puede verse en: MOORE, Robin (2002), Música y mestizaje. Revolución artística y cambio social en La Habana. 1920-1940, Colibrí, Madrid.

12. Alexandre Arrechea, White Corner, 2006, vídeo instalación, loop, color, sonido.

https://alexandrearrechea.com/works/white-corner/

Los Carpinteros, Pellejo, 2013, vídeo HD, 16:9, B/N, sonido, 11:12 min.

Los Carpinteros fue un colectivo formado por Marco Castillo (Camagüey, 1971) y Dagoberto Rodríguez (Caibarién, 1969) entre 1991-2018, también fue fundador y perteneció a éste Alexandre Arrechea entre 1991 y 2003. Con una amplia trayectoria artística, este grupo ha sido reconocido como una de las figuras más influyentes y de mayor visibilidad internacional del arte cubano contemporáneo desde la década de los 90 , con residencias y exposiciones en museos, bienales y ferias de gran prestigio a nivel global. 
13. El bilbaíno Víctor Patricio de Landaluze legó a la historia del arte cubano la representación canónica del cimarrón. Su lienzo homónimo de 1874, será reiteradamente fijado como prototexto en la obra de diferentes artistas donde la afrodescendencia se negocia a partir de la idea de resistencia que simboliza el cimarronaje como práctica emancipatoria y cultural. Otro texto de referencia insoslayable en la caracterización del cimarronaje es la novela testimonio de Miguel Barnet, realizada a partir de un conjunto de entrevistas donde Esteban Montejo, un anciano centenario, narra sus memorias. Véase: BARNET, Miguel (1966), Biografía de un cimarrón, Instituto de Etnología y Folklore, Academia de Ciencias de Cuba, La Habana.

14. Aunque no los analicemos en este texto, es menester citar otros dos trabajos en vídeo de Alexandre Arrechea en los que aparecen cuestiones relativas al mito viril del cuerpo negro y la criminalización del mismo, respectivamente: Lament For Ben, 2003, vídeo, 4:50 min; La nariz un poco más larga, 2003. También, aunque trasciende nuestro objeto de estudio para este artículo, en relación con la representación de masculinidades negras es importante mencionar el trabajo del joven creador Javier Castro, fundamentalmente una obra como Reconstruyendo al héroe, 2006; así como los registros en vídeo de las performances de Carlos Martiel desde el año 2007 hasta la actualidad.

En el fútbol el córner es un modo de reanudación del juego. La obra White Corner fue realizada por Alexandre Arrechea justo a su salida del colectivo Los Carpinteros para iniciar una carrera en solitario. Para una lectura alternativa de esta pieza puede verse: http://www.withoutmasks.org/ portfolio/white-corner/

15.

Raychel Carrión, Fallas de origen, 2007, vídeo, color, sonido, 17 min.

16. Los Carpinteros, Polaris, 2014, vídeo HD, color, sonido, 10:40min.

17. Juego de palabras que establece una paráfrasis con la conocida frase del escritor nigeriano Wole Soyinka: "Un tigre no grita su tigritud: salta. Un tigre en la selva no dice: soy un tigre. Solo al pasar por el terreno de caza del tigre y encontrar el esqueleto de una gacela sentimos que el lugar desborda tigritud". En este caso se utiliza el simbolismo del sonido de la tumbadora como elemento poético que condensa la voz de la cultura afrocubana y la memoria de la diáspora africana; así como vehículo para la agencia política afrodescendiente.

\section{RESÚMENES}

En los vídeos de un grupo de jóvenes artistas cubanos donde ha sido representado el cuerpo masculino negro, el silencio se establece como recurso que tensiona la obliteración de las voces afrodescendientes en los regímenes de enunciación del discurso político en Cuba. La presencia silenciosa del hombre negro solitario frente a la cámara se articula en tanto resignificación del cuerpo afrodescendiente en el espacio de la ciudad, como una energía de disenso y resistencia que traspasa el contexto privado para irrumpir en la esfera pública como un signo de pluralidad, orgullo y diferencia. Ese silencio reinscribe la violencia fundacional del Estado y la colonialidad persistente en los imaginarios sociales sobre un sujeto históricamente subalternizado y marginalizado por ideologías racistas modernas.

Dans les vidéos d'un groupe de jeunes artistes cubains, où le corps masculin noir a été représenté, le silence apparaît comme une ressource qui souligne l'effacement des voix des descendants africains dans le discours officiel à Cuba. Cette présence silencieuse de l'homme noir, solitaire, devant la caméra, donne un nouveau sens au corps afrodescendant dans l'espace urbain. Il devient une sorte d'énergie dissidente et de résistance qui intervient dans l'espace public, comme un signe de pluralité, de fierté et de différence. Un silence qui revient sur une certaine violence innée de l'État, mais aussi d'une pensée coloniale persistante dans 
l'imaginaire social, à propos d'un sujet historiquement subalternisé et marginalisé par les idéologies racistes modernes.

\section{ÍNDICE}

Palabras claves: Afrodescendencia, racismo, masculinidades, colonialidad, cuerpo, performatividad, silencio.

Mots-clés: afro-descendants, racisme, masculinités, colonialité, corps, performativité, silence.

\section{AUTOR}

\section{SUSET SÁNCHEZ SÁNCHEZ}

Suset Sánchez es Licenciada en Historia del Arte por la Universidad de La Habana y Máster en Historia del Arte Contemporáneo y Cultura Visual por la Universidad Autónoma de Madrid, Universidad Complutense y Museo Nacional Centro de Arte Reina Sofía. Curadora y crítica de arte. Beca de Investigación Departamento de Exposiciones Museo Nacional Centro de Arte Reina Sofía (2017-2021).

susetsanchez@yahoo.com 